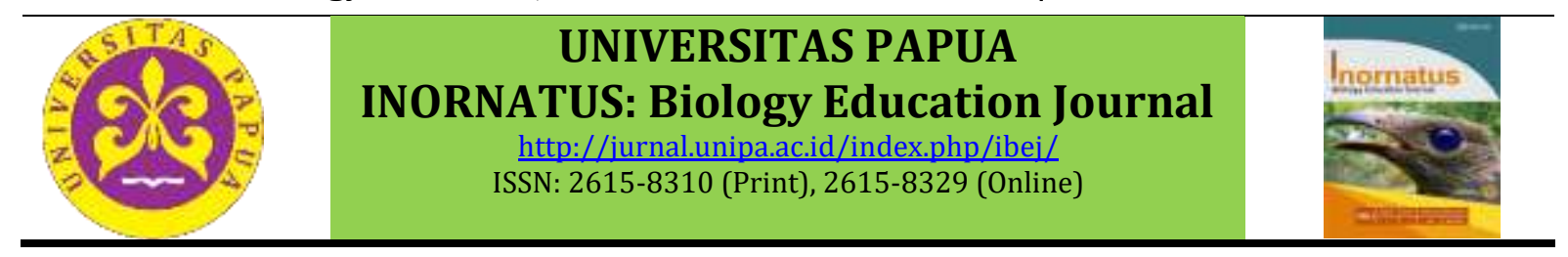

\title{
The effectiveness of laboratory use in supporting biology practicums in high schools throughout Manokwari Regency
}

\section{Efektivitas penggunaan laboratorium dalam menunjang praktikum biologi di SMA se Kabupaten Manokwari}

\author{
Ronal F Frabun, Iwan*, Hengky L. Wambrauw \\ Pendidikan Biologi FKIP Universitas Papua \\ *korespondensi penulis : b.iwan@unipa.ac.id
}

\begin{abstract}
This study aims to analyze the effectiveness of laboratory used in practices biology field at Two Senior high school, called SMA in Manokwari regency. This study is a qualitative-descriptive. The data collected by observation sheets, or quistionnaries. that answered by two teachers and six students. The result showed that SMA Negeri 1 Prafi effectivelly in used laboratory for doing practices or effectively categorized by $74,72 \%$ and SMA Katolik Villanova reached up and average $67.56 \%$ means to support the laboratory Experient or categorized as effective. While obstacles of the Two school still high reached up $80 \%$, while the percentage of the standardized laboratory equipments are familier spread from $49 \%-51 \%$.
\end{abstract}

Keywords: Effectivelly, laboratory, Biologi, SMA

\begin{abstract}
Abstrak
Penelitian ini bertujuan untuk menganalisis efektivitas laboratorium yang digunakan dalam praktik bidang biologi di SMA Dua, yang disebut SMA di Kabupaten Manokwari. Penelitian ini adalah kualitatifdeskriptif. Data dikumpulkan dengan lembar observasi, atau quistionnaries. yang dijawab oleh dua guru dan enam siswa. Hasil penelitian menunjukkan bahwa SMA Negeri 1 Prafi efektif digunakan di laboratorium yang digunakan untuk melakukan praktik atau secara efektif dikategorikan sebesar 74,72\% dan SMA Katolik Villanova mencapai dan rata-rata 67,56\% berarti mendukung laboratorium Experient atau dikategorikan sebagai efektif. Sementara hambatan dari Dua sekolah masih tinggi mencapai 80\%, sementara persentase peralatan laboratorium standar adalah keluarga yang tersebar dari $49 \%-51 \%$.
\end{abstract}

Kata Kunci: efektivitas, laboratorium Biologi, SMA

\section{Pendahuluan}

Pendidikan adalah proses pengubahan sikap dan tatalaku seseorang atau kelompok orang dalam usaha mendewasakan manusia melalui upaya pengajaran dan pelatihan, proses, cara, perbuatan mendidik Menurut UU No. 20 tahun 2003, pendidikan adalah usaha sadar dan terencana untuk mewujudkan suasana belajar dan proses pembelajaran agar peserta didik secara aktif mengembangkan potensi dirinya untuk memiliki kekuatan spritual keagamaan, pengendalian diri, kepribadian, kecerdasan akhlak mulia serta ketrampilan yang diperlukan dirinya, masyarakat, bangsa dan Negara.

Standar Nasional pendidikan mencakup 8 standar Nasional pendidikan : Standar Kompetensi lulusan, Standar Isi, Standar Proses, Standar Pendidikan dan Tenaga Kependidikan, Standar Sarana dan Prasarana, Standar Pengelolaan, Standar Pembiayaan Pendidikan, Standar penilaian Pendidikan. Fungsi dan tujuan Standar Nasional pendidikan sebagai dasar dalam perencanaan, pelaksanaan, dan pengawasan pendidikan dalam mewujudkan pendidikan Nasional yang bermutu. Standar sarana 
dan prasarana, Setiap satuan Pendidikan wajib memiliki sarana yang meliputi perabot, peralatan pendidikan, media pendidikan, buku dan sumber belajar, lahan, ruang kelas, ruang pimpinan, satuan pendidik, ruang tata usaha, ruang perpustakaan, ruang laboratorium, ruang bengkel kerja, ruang unit produksi, ruang kantin, instalasi, tempar berolahraga, dan ruang/tempat lainnya yang diperlukan untuk menunujang proses pembelajaran yang teratur dan berkelanjutan. Menurut Permendiknas Nomor 24 Tahun 2007 Standar sarana dan prasana Untuk SMP/MTS, dan SMA/MA

Laboratorium IPA merupakan tempat untuk mengaplikasikan teori keilmuan, pengujian teoritis, pembuktian ujicoba, penelitian, dan sebagainya dengan menggunakan alat bantu yang menjadi kelengkapan dari fasilitas dan kauntitas dan kaulitas yang memadai. Menurut Damopolii, Hasan \& Kandowango (2015) bahwa Pemahaman terhadap bukti ilmu pengetahuan dan cara-cara mengumpulkan bukti ilmu pengetahuan dapat diperoleh melalui kegiatan praktikum dan salah satu tempat pelaksanaan praktikum adalah laboratoriumLaboratorium IPA berfungsi sebagai tempat berlangsungnya kegiatan pembelajaran yang memerlukan peralatan khusus yang tidak mudah di hadirkan di dalam ruang kelas. Dalam konteks pendidikan di sekolah, Laboratorium mempunyai fungsi sebagai tempat proses pembelajaran dengan metoda praktikum yang memberikan pengalaman belajar pada siswa untuk berinteraksi dengan alat dan bahan serta mengobservasi berbagai gejala secara langsung (Sutrisno, 2007).

Hasil pemantauan dan evaluasi yang telah dilakukan oleh Direktorat Pendidikan Menengah Umum dan Inspektorat Jenderal Pendidikan Dasar dan Menengah, diperoleh informasi bahwa masih banyak Laboratorium Biologi (secara umum laboratorium Ilmu pengetahuan Alam/IPA) yang belum dimanfaatkan sebagaimana mestinya, bahkan pengelolaan dan pemanfaatannya sebagai sumber belajar belum optimal atau ada yang belum digunakan sama sekali, masalah tersebut disebabkan oleh berbagai macam faktor. Hal ini menyebabkan siswa yang belajar Biologi yang bersifat hafalan. Sehingga menjadi kurang bermakna dan berdampak pada pembelajaran sehingga tidak terjadi perubahan pada pengetahuan \& psikomotorik.

Standar laboratorium IPA di SMA memiliki peranan penting dalam memfasilitasi peserta didik dalam kegiatan belajar mengajar. Untuk mencapai kompetensi belajar yang diharapkan maka diperlukan fasilitas yang mamadai. begitu pula dengan kegiatan praktikum IPA di laboratorium, agar praktikum berjalan dengan lancar dan memperoleh hasil pemahaman kepada peserta didik secara optimal maka diperlukan fasilitas yang memadai yaitu laboratorium IPA yang terstandar sesuai dengan Permendiknas No. 24 Tahun 2007.

Dalam peraturan tersebut, telah dijelaskan secara rinci standar minimal laboratorium IPA di SMA yang terdiri dari laboratorium Biologi, Fisika, dan Kimia. Adapun standar Laboratorium Biologi tersebut adalah sebagai berikut : Ruang laboratorium biologi berfungsi sebagai tempat berlangsungnya kegiatan pembelajaran biologi secara praktik yang memerlukan peralatan khusus, ruang laboratorium biologi dapat menampung minimum satu rombongan belajar, ruang laboratorium biologi memiliki fasilitas yang memungkinkan pencahayaan memadai untuk membaca buku dan mengamati obyek percobaan. Sarana dalam Laboratorium Biologi.

Sarana laboratorium biologi terdiri dari perabot seperti meja, kursi, almari, dan bak cuci, peralatan pendidikan yaitu papan tulis, bahan habis pakai dan perlengkapan lainnya seperti keranjang sampah, jam dinding, serta peralatan P3K. Berdasarkan hasil observasi, SMA Negeri dan Swasta yang ada di Manokwari, terdapat 2 sekolah, SMA Negeri 1 Prafi dan SMA Katholik Villanova Manokwari, yang mempunyai laboratorium, dan sejauh mana penggunaan laboratorium untuk kepentingan praktikum Biologi dalam 
menunjang kegiatan belajar mengajar belum ada informasi yang akurat. Hal itulah yang melatar belakangi penulis untuk meneliti tentang Efektifitas Penggunaan Laboratorium Biologi dalam Menunjang Kegiatan Praktikum di SMA Negeri 1 Prafi, dan SMA Katolik Villanova Manokwari.

\section{Metode}

Metode penelitian yang digunakan dalam penelitian ini deskriptif kualitatif. Instrumen penelitian yang digunakan berupa ; Lembar observasi, angket (kuisioner), dengan teknik wawancara dan dokumentasi. Observasi yang dilakukan meliputi pengamatan terhadap kondisi Laboratorium, ketersediaan perlengkapan, dan peralatan yang mendukung efektifnya Praktikum Biologi di SMA.

Wawancara dilakukan terhadap guru biologi Informasi yang didapat melalui wawancara meliputi frekuensi penggunaan laboratorium, ketersediaan alat dan bahan dalam kegiatan praktek intensitas (frekuensi). praktikum apa saja yang dilakukan dan efektif tidaknya penggunaan laboratorium. Angket (kuisioner) diberikan pada guru Biologi dan siswa Angket (kuisioner) diperlukan untuk mengetahui jenis praktikum yang dilakukan efektif atau tidak. Populasi dalam penelitian ini adalah guru dan siswa di SMA Negeri 1 Prafi dan SMA Katolik Villanova Manokwari. Sampel dalam penelitian ini adalah guru biologi dan satu orang siswa per kelas X, XI, XII. Atau pengambilan sampel dilakukan secara (purposive sampling).

Teknik pengumpulan data yang digunakan dalam penilitian ini yaitu:

1. Observasi atau pengamatan ini dilakukan untuk melihat dan mengamati secara langsung desain ruang laboratorium Biologi, pengecekan ketersediaan alat dan Bahan praktikum Biologi. Untuk memudahkan peniliti melihat dan mengamati secara langsung penggunaan Laboratorium. Adapun Instrumen yang akan digunakan dalam observasi ini terdiri atas :

a. Lembar observasi Laboratorium, digunakan untuk mengetahui secara umum keadaan Laboratorium IPA.

b. Angket, digunakan untuk membantu peneliti dalam mengumpulkan data awal.

c. Tabel data alat Bahan Laboratorium, digunakan sebagai pedoman untuk melihat syarat standar Laboratorium.

d. Kamera, digunakan untuk mendokumentasi proses pengambilan Data.

e. Alat perekam suara (Recorder), digunakan untuk memudahkan peneliti dalam mengambil Data.

2. Angket (Kuisioner)

Angket merupakan teknik pengumpulan data yang digunakan dengan cara memberikan pertanyaan tertulis kepada responden untuk dijawabnya. Bentuk angket yang diguanakan yaitu bersifat pertanyaan tertutup.

Adapun skala pengukuran yang digunakan dalam angket penelitian ini yaitu angket dengan skala Guttman, merupakan angket dengan tipe jawaban tegas yakni "Ya" atau "Tidak".

\section{Wawancara}

Wawancara dilakukan terhadap guru mata pelajaran Biologi setiap kelas X, XI, XII di dua sekolah yaitu; SMA Negeri 1 Prafi, dan SMA Katolik Vilanova Manokwari.

\section{Dokumentasi}

Dokumentasi yang dilakukan berupa gambar-gambar data sekunder berupa : Alat, bahan, Perangkat pembelajaran, Buku-buku pegangan Guru dan LKS. 
Teknik analisis data digunakan yaitu statistik sederhana, (persentase) efektif atau tidak efektifnya penggunaan laboratorium dalam kegiatan praktikum. Adapun rumus yang digunakan yaitu :

$$
\mathrm{P}=\frac{f}{N} \mathrm{X} 100
$$

\section{Keterangan :}

$P=$ Persentase $(\%)$

$f=$ Jumlah subjek yang ada pada kategori tertentu

$N=$ Frekuensi total atau keseluruhan jumlah subyek

Jadi untuk angket dengan skala Guttman, skor, terendah 0\% dan skor tertinggi 100\% sehingga ditentukan interval nilai sebagai berikut :

Tabel 1. Interval nilai angket Guttman (Arikunto, 2010)

\begin{tabular}{cc}
\hline Interval Skor & Kategori \\
\hline $81 \%-100 \%$ & Sangat Efektif \\
$61 \%-80 \%$ & Efektif \\
$41 \%-60 \%$ & Cukup Efektif \\
$21 \%-40 \%$ & Kurang Efektif \\
$0-20 \%$ & Tidak efektif \\
\hline
\end{tabular}

\section{Hasil dan Pembahasan}

Berdasarkan hasil penelitian SMA Negeri dan Swasta di kota manokwari yang menjadi sampel penelitian adalah SMA Negeri 1 Prafi dan SMA Katolik villanova. Berdasarkan hasil observasi awal di lapangan pada laboratorium IPA dengan menggunakan data angket, wawancara dan dokumentasi, terlihat bahwa laboratorium yang berada di SMA Negeri 1 Prafi berjumlah 1 unit laboratorium IPA, yang digunakan untuk pelaksanaan praktikum Fisika, Kimia dan Biologi, sehingga hal ini yang menjadi hambatan utama dalam proses pelaksanaan praktikum Biologi. SMA Katolik villanova Manokwari memiliki lokasi sekolah yang sangat strategis kondisi lingkungan sekolah baik, aman karena terdapat pihak keamanan yang selalu menjaga lingkungan sekolah dengan baik. Laboratorium yang terdapat di SMA Katolik Villanova Manokwari berjumlah 2 unit laboratorium yang terdiri 1 unit laboratorium fisika 1 unit terdiri dari Laboratorium Kimia dan Biologi dan dilengkapi dengan alat dan bahan penunjang pelaksanaan praktikum dan alat keselamatan kerja.

Tabel 2 Pandangan guru terhadap Efektivitas penggunaan Laboratorium di SMA Negeri Prafi Manokwari.

\begin{tabular}{clc}
\hline No & Jenis Kegiatan & Kategori (\%) \\
\hline 1 & Keadaan laboratorium & $100 \%$ \\
2 & Waktu pelaksanaan praktikum & $100 \%$ \\
3 & Persiapan dan pelaksanaan & $75 \%$ \\
4 & Laporan dan evaluasi praktikum & $100 \%$ \\
5 & Hambatan dalam pelaksanaan praktikum & $80 \%$ \\
6 & Faktor penunjang efektif pelaksanaan praktikum & $33,3 \%$ \\
\hline & & Rata-rata (\%) \\
\hline
\end{tabular}


Tabel 3. Pandangan siswa terhadap Efektivitas penggunaan Laboratorium di SMA Negeri 1 Prafi Manokwari

\begin{tabular}{clc}
\hline No & Jenis Kegiatan & Kategori (\%) \\
\hline 1 & Keadaan laboratorium & $61.11 \%$ \\
2 & Waktu pelaksanaan praktikum & $91.67 \%$ \\
3 & Persiapan dan pelaksanaan & $41.67 \%$ \\
4 & Laporan dan evaluasi praktikum & $100 \%$ \\
\hline \multicolumn{2}{r}{ Rata-rata (\%) } \\
\hline
\end{tabular}

Tabel 3 menunjukan bahwa penggunaan laboratorium di SMA Negeri prafi Manokwari dengan nilai rata-rata persentase $73,61 \%$ dari keempat jenis kegiatan yaitu : keadaan laboratorium 61,11\%, waktu pelaksanaan praktikum 91,67\%, persiapan dan pelaksanaan 41,67\%, laporan dan evaluasi 100\%, Dari hasil yang dicapai maka proses penggunaan laboratorium di SMA Negeri 1 prafi manokwari sudah efektif.

Tabel 4 Pandangan guru terhadap Efektivitas penggunaan Laboratorium di SMA Katolik Villanova Manokwari.

\begin{tabular}{clc}
\hline No & Jenis Kegiatan & Kategori (\%) \\
\hline 1 & Keadaan laboratorium & $60 \%$ \\
2 & Waktu pelaksanaan praktikum & $75 \%$ \\
3 & Persiapan dan pelaksanaan & $75 \%$ \\
4 & Laporan dan evaluasi praktikum & $100 \%$ \\
5 & Hambatan dalam pelaksanaan praktikum & $80 \%$ \\
6 & Faktor penunjang efektif pelaksanaan & $33.3 \%$ \\
& praktikum & $\mathbf{7 0 , 5 5 \%}$ \\
\hline
\end{tabular}

Tabel 4 menunjukan bahwa penggunaan laboratorium di SMA Katolik Villanova Manokwari dengan nilai rata- rata persentase $70,55 \%$ dari keenam jenis kegiatan yaitu : keadaan laboratorium 60\%, waktu pelaksanaan praktikum 75\%, persiapan dan pelaksanaan $75 \%$, laporan dan evaluasi praktikum $100 \%$, hambatan dalam pelaksanaan praktikum $80 \%$, faktor penujang efektif pelaksnaan praktikum 33,3\%. Dari hasil yang dicapai maka proses penggunaan laboratorium di SMA Katolik Villanova Manokwari efektif.

Tabel 5. Pandangan siswa terhadap Efektivitas penggunaan Laboratorium di SMA Katolik Villanova Manokwari

\begin{tabular}{clc}
\hline No & Jenis Kegiatan & Kategori (\%) \\
\hline 1 & Keadaan laboratorium & $33.33 \%$ \\
2 & Waktu pelaksanaan praktikum & $75 \%$ \\
3 & Persiapan dan pelaksanaan & $50 \%$ \\
4 & Laporan dan evaluasi praktikum & $100 \%$ \\
\hline & Rata-rata (\%) & $\mathbf{6 4 , 5 8 \%}$ \\
\hline
\end{tabular}


Tabel 5 menunjukan bahwa penggunaan laboratorium di SMA Katolik Villanova Manokwari dengan nilai rata-rata persentase 64,58\% dari keempat jenis kegiatan yaitu : keadaan laboratorium 33,3\%, waktu pelaksanaan praktikum 75\%, persiapan dan pelaksanaan 50\%, laporan dan evaluasi 100\%. Dari hasil yang dicapai maka proses penggunaan laboratorium di SMA Katolik Villanova manokwari efektif. Rekapan Efektivitas penggunaan laboratorium di SMA Negeri 1 prafi dan SMA Katolik villanova Manokwari dapat dilihat pada grafik

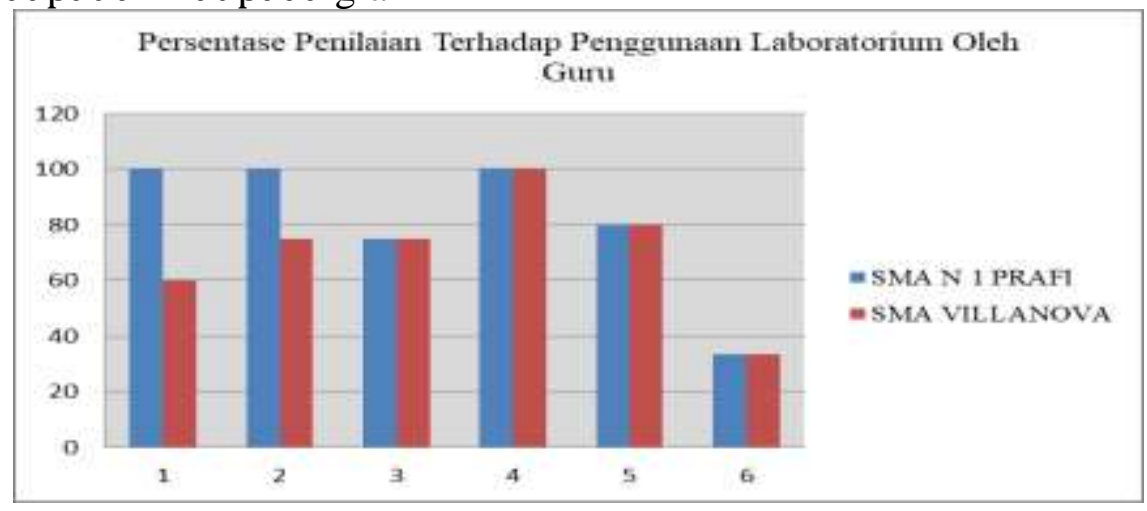

Gambar 1. Penilaian penggunaan laboratorium oleh guru

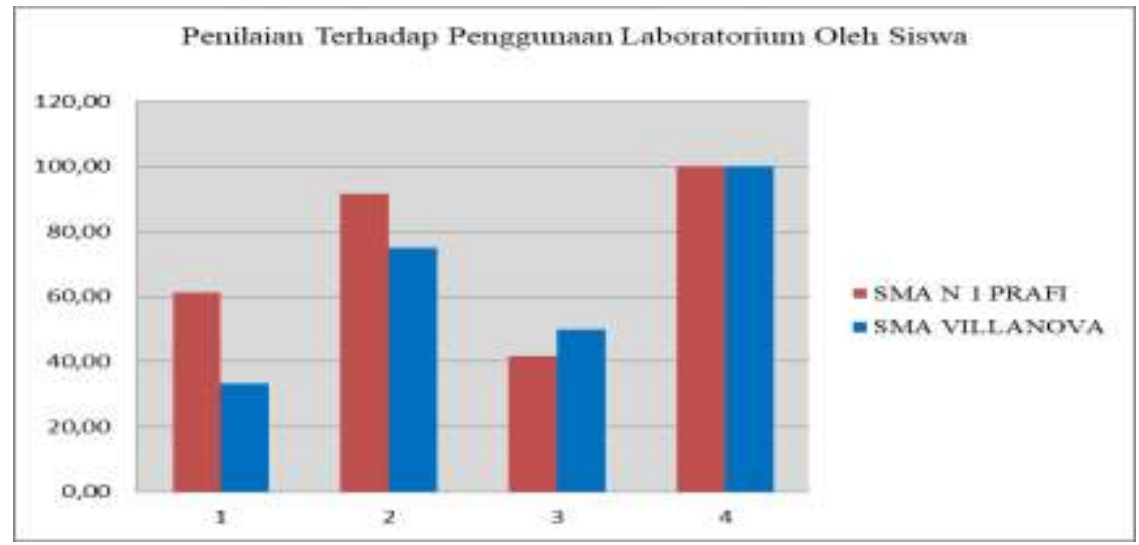

Gambar 2. Penilaian penggunaan laboratorium oleh siswa

\section{Efektivitas penggunaan laboratorium IPA/Biologi di SMA Negeri 1 Prafi}

Berdasarkan data hasil wawancara dan observasi dilapangan yang dilakukan di masing-masing sekolah di dapat bahwa sarana yang ada dilaboratorium IPA/Biologi SMA Negeri 1 prafi dilihat dari persentase efektivitas penggunaan laboratorium IPA/Biologi pada Tabel 1.3 tentang efektivitas penggunaan laboratorium yang meliputi beberapa kegiatan yaitu : keadaan Laboratorium persentase pengunaan mencapai $100 \%$ digunakan dengan efektif, waktu pelaksanaan praktikum persentase mencapai $100 \%$ dilaksanakan dengan efektif hal ini dapat dilihat dari keaktifan siswa saat mengikuti proses praktikum. persiapan dan pelaksanaan persentase mencapai $75 \%$ terlaksana tetapi $25 \%$ tidak terlaksana karena tidak memiliki tenaga laboran yang berfungsi untuk menyiapkan semua kebutuhan pelaksanaan praktikum dan dengan kondisi laboratorium yang masih tergabung Biologi dan kimia sehingga pelaksaan praktikum Biologi terhambat. Menurut Marathus (2013), frekuensi pemanfaatan laboratorium yang efektif atau kategori baik 61\%-80. Hal ini dapat dilihat dari beberapa indikator kefektifan penggunaan laboratorium dalam pembelajaran menurut Yawarmansyah (2011) ada 4 yaitu : 
1. Frekuensi penggunaan laboratorium.

2. Kelengkapan alat-alat yang ada dilaboratorium.

3. Kesesuaian materi dengan alat yang tersedia dilaboratorium.

4. Lokasi waktu yang cukup untuk kegiatan praktikum.

laporan dan evaluasi praktikum mencapai $100 \%$ hal ini dilihat dari antusias siswa saat mengikuti praktikum mereka aktif saat melakukan pengamatan dan melaporkan hasil pengamatan tersebut baik secara kelompok maupun individu. hambatan dalam pelaksanaan praktikum mencapai $80 \%$. Hal ini dapat dilihat dari jawaban responden dalam hal pelaksanaan kegiatan praktikum meskipun hambatan cukup berpengaruh tetapi praktikum tetap berlangsung meskipun tidak didalam ruang laboratorium, tetapi dilingkungan sekolah, faktor penunujang efektif pelaksanaan praktikum persentase mencapai 33,3\% dilaksanakan tetapi 66,7 tidak terlaksana karena belum memiliki tenaga laboratorium dan teknisi sehingga guru mengalami kesulitan untuk melakukuan kegiatan praktikum di laboratorium karena guru harus menyiapkan sendiri alat dan bahan yang akan digunakan untuk kegiatan praktikum, sedangkan waktu atau jam pelajaran yang dimiliki guru tidak cukup atau kurang. Berdasarkan hasil wawancara, terhadap guru bahwa kendala utama yang dihadapi yaitu kurangnya tenaga laboran dan teknisi sehingga alat dan bahan yang tersedia dilaboratorium menjadi tidak terawat dengan baik misalnya mikroskop dan kaca preparat dan bahan larutan jika tidak di bersihkan akan ditumbuhi jamur dan larutan kadaluarsa sehingga tidak dapat digunakan lagi (wawancara 14 februari 2018).

Berdasarkan data hasil angket (kuisioner) dan wawancara dalam hal pelaksanaan kegiatan praktikum di SMA Negeri 1 Prafi sudah berjalan efektif ketersedian alat dan bahan praktek untuk kegiatan praktek sudah sangat memadai hasil wawancara diketahui bahwa untuk mendapatkan alat dan bahan praktikum tidak harus guru yang menyiapkan dan memperolehnya dilaboratorium seluruhnya tetapi siswa juga diberi tugas untuk menyiapkan bahan praktikum sendiri baik dalam bentuk kelompok atau individu untuk menyiapkan bahan yang akan dipakai. Fasilitas umum laboratorium yang ada di SMA Negeri 1 Prafi digunakan khusus untuk praktikum sehingga tidak terganggu oleh ativitas kegiatan belajar mengajar di kelas.

\section{Efektiftivitas penggunaan laboratorium IPA/Biologi di SMA Katolik Villanova Manokwari}

Dari hasil angket (kuisoner) dan wawancara yang dilakukan tentang efektivitas penggunaan laboratorium IPA/Biologi dengan kategori dan jenis kegiatan yaitu : keadaan laboratorium persentase mencapai $60 \%$ terlaksana sedangkan $40 \%$ tidak terlaksana yaitu karena didalam laboratorium belum memiliki alat dan bahan laboratorium yang mendukung pelaksanaan praktikum Biologi. waktu pelaksanaan praktikum persentase mencapai $75 \%$ terlaksana sedangkan $25 \%$ tidak terlaksana karena guru tidak memberikan modul/penuntun praktikum kapada siswa sehingga guru harus menjelaskan prosedur langkah-langkah kerja. Persiapan dan pelaksanaan praktikum persentase mencapai $75 \%$ terlaksana sedangkan $25 \%$ tidak terlaksana hal ini disebabkan karena kurangnya waktu pembelajran yang sangat singkat sedangkan banyak topik yang harus dibahas dan di praktekan. Laporan dan evaluasi praktikum persentase mencapai $100 \%$ hal ini terlihat oleh antusias siswa dalam mengikuti kegiatan praktikum dilaboratorium mereka selalu aktif dan setelah kegiatan praktikum selesai setiap siswa baik secara individu maupun kelompok melaporkan hasil pengamatan dan guru memberikan penilaian. Permasalahan (hambatan) dalam 
keefektivan praktikum persentase mencapai $80 \%$. Hal ini dapat dilihat dari jawaban responden dalam hal pelaksanaan kegiatan praktikum meskipun hambatan cukup berpengaruh tetapi praktikum tetap berlangsung meskipun tidak didalam ruang laboratorium, tetapi diruang kelas dan lingkungan sekolah.

Berdasarkan hasil wawancara dan kuisioner guru sering mengalami kendala baik kekurangan alat dan bahan praktikum dan juga waktu, siswa juga mengalami kesulitan mengoperasikan alat-alat praktikum karena belum memiliki modul atau penuntun praktikum sehingga proses praktikum terhambat. Faktor penunjang pelaksanaan praktikum persentase mencapai 33,3\% terlaksana sedangkan 66,7\% tidak terlaksana hal ini disebabkan karena SMA Katolik Villanova belum memliki tenaga laboran dan tenaga administrasi sehingga kurangnya perhatian terhadap laboratorium hal tersebut yang menjadi kendala utama bagi guru untuk melaksanakan kegiatan praktikum.

Berdasarkan data hasil angket (kuisioner) dan wawancara dalam hal pelaksanaan kegiatan praktikum di SMA Katolik Villanova sudah berjalan efektif ketersedian alat dan bahan praktek untuk kegiatan praktek sudah sangat memadai hasil wawancara diketahui bahwa, untuk mendapatkan bahan praktikum siswa tidak harus memperolehnya dari laboratorium tetapi juga bias membawa dari rumah dan lingkungan sekitar sesuai dengan perintah guru. Fasilitas umum yang ada di ruang laboratorium biologi meliputi penerangan (listrik) untuk keperluan lampu, bak cuci, sedangkan fasilitas khusus meliputi meja demonstrasi, meja persiapan dimana guru mempersiapkan alat dan bahan, buku panduan, persiapan waktu, meja praktikum, meja guru, kursi guru, kursi siswa, lemari penyimpan alat dan bahan, serta alat pemadamam kebakaran.

Berdasarkan hasil wawancara guru di SMA Katolik villanova memanfaatkan laboratorium IPA/Biologi sebagai salah satu sarana pendidikan dengan melakukan praktikum dalam mendukung pelaksanaan proses pembelajaran akan tetapi guru juga menggunakan metode lain dalam pembelajaran.

Dari hasil wawancara SMA Negeri 1 prafi dan SMA Katolik Villanova tidak semua kegiatan praktikum yang dilaksanakan selalu berhasil sering mengalami kegagalan karena ada alat dan bahan yang rusak atau kadaluarsa atau terkontaminasi oleh zat lain guru kadang sulit untuk mengontrol siswa. Adapun cara yang digunakan untuk mengatasi kegagalan atau kesulitan tersebut dengan cara memeriksa alat dan bahan yang akan digunakan terlebih dahulu mengingatkan siswa tentang cara penggunaan alat dan keselamatan kerja.

\section{Ketersediaan alat dan bahan praktikum di SMA Negeri 1 Prafi dan SMA Katolik Villanova Manokwari}

Berdasarkan data hasil penelitian laboratorium IPA/Biologi SMA Negeri 1 Prafi Manokwari sudah mempunyai desain ruang laboratorium yang sangat sesuai untuk pelaksanaan praktikum laboratorium tersebut menempati luas $12 \mathrm{~m}$, panjang $15 \mathrm{~m}$, dan tinggi 9m dengan kapasitas siswa setiap praktikum sebanyak 20-40 siswa. Untuk kegiatan praktikumnya siswa biasanya dalam bentuk kelompok dimana setiap kelompoknya sebanyak 4-5 orang.

Ketersedian alat dan bahan untuk kegiatan praktikum belum memadai dengan petsentase 51\%. Dari hasil wawancara, diketahui bahwa untuk mendapatkan alat dan bahan praktikum siswa tidak harus memperolehnya dari laboratorium tetapi juga dapat membawa dari rumah sesuai perintah guru atau dari lingkungan yang ada disekitar sekolah. Fasilitas umum yang ada diruang laboratorium biologi meliputi penerangan 
(listrik) untuk keperluan lampu, ventilasi udara, sehingga pertukaran udara diruangan lancar dan tidak lembab bak cuci/westafel.

Fasilitas khusus meliputi meja demonstrasi, meja persiapan,meja praktikum, meja guru, kursi guru dan siswa, papan tulis, lemari penyimpanan alat, lemari penyimpanan bahan, dan kotak P3K.

Laboratorium IPA/Biologi SMA Katolik Villanova Manokwari Berdasarkan data hasil penelitian laboratorium IPA/Biologi SMA Katolik Villanova Manokwari sudah mempunyai desain ruang laboratorium yang sangat sesuai untuk pelaksanaan praktikum laboratorium tersebut menempati luas $10 \mathrm{~m}$, panjang $12 \mathrm{~m}$, dan tinggi $5 \mathrm{~m}$. dengan kapasitas siswa setiap praktikum sebanyak 20-30 siswa. Untuk kegiatan praktikumnya siswa biasanya dalam bentuk kelompok dimana setiap kelompoknya sebanyak 4-5 orang.

\section{Simpulan}

Berdasarkan hasil penelitian dapat disimpulkan bahwa Analisis efektivitas penggunaan laboratorium Biologi di beberapa SMA Negeri dan Swasta di Manokwari Tahun ajaran 2017/2018 bahwa Penggunaan laboratorium di SMA Negeri 1 Prafi Manokwari dari pandangan guru dan siswa dikategorikan efektif $(74,72 \%)$ dan penggunaan laboratorium di SMA Katolik Villanova Manokwari dari pandangan guru dan siswa juga dikategorikan efektif $(67,56 \%)$. Hal ini didukung oleh ketersediaan alat dan bahan praktikum yaitu, SMA Negeri 1 Prafi dikategorikan cukup (51\%) dan SMA Katolik Villanova juga dikategorikan cukup (49\%). Sedangkan hambatan dalam pelaksanaan praktikum di kedua sekolah tersebut walaupun mencapai $80 \%$, tetapi dapat teratasi melalui kegiatan praktikum lapangan diluar laboratorium (lingkungan sekolah) berhubungan dengan makna pembelajaran kurikukulum 2013 (K13).

\section{Referensi}

Arikunto, S. (2003). Prosedur Penilitian Suatu Pendekatan Praktik. Jakarta: Rineka Cipta. Damopolii, I., Hasan, A., \& Kandowangko, N. (2015). Pengaruh Strategi Pembelajaran Inkuiri Bebas Dimodifikasi dan Kemampuan Memecahkan Masalah terhadap Keterampilan Proses Sains Mahasiswa Pada Praktikum Fisiologi Tumbuhan. Pancaran Pendidikan, 4(3), 191-200.

Permendiknas No. 24 Tahun 2007 Tentang standar sarana prasarana. Bandung 2008

Sutrisno W. (2007) Pengelolaan Fasilitas Lab Fisika Untuk Diklat Teknisi Lab. Pusat Pengembangan dan Pemberdayaan Pendidik dan Tenaga Kependidikan IPA. Bandung.

Yawarmansyah, W. (2011) Efektifitas Penggunaan Laboratorium Dalam Menunjang Kegiatan Praktikum Di SMA se-Kabupaten Lombok Tengah. 